\title{
Microcredit in Bangladesh: Impact on Borrowers' Social Mobility Revisited
}

\author{
Ashfaq Ferdous* ${ }^{(0)}$, Salma Begum, Jannaty Akter \\ Department of Sociology, Faculty of Social Sciences, University of Dhaka, Dhaka, Bangladesh \\ Email:*ashfaq.ferdous@gmail.com:
}

How to cite this paper: Ferdous, A., Begum, S., \& Akter, J. (2020). Microcredit in Bangladesh: Impact on Borrowers' Social Mobility Revisited. Open Journal of Social Sciences, 8, 163-180.

https://doi.org/10.4236/jss.2020.87014

Received: June 14, 2020

Accepted: July 14, 2020

Published: July 17, 2020

Copyright $\odot 2020$ by author(s) and Scientific Research Publishing Inc. This work is licensed under the Creative Commons Attribution International License (CC BY 4.0).

http://creativecommons.org/licenses/by/4.0/ (c) (i) Open Access

\begin{abstract}
In Bangladesh, microcredit program has been in function for almost half a century. Though popularly termed as a tool for poverty alleviation and women empowerment, criticism about microcredit program's actual effectiveness isn't new. This study attempts to evaluate the impact of such programs by measuring borrowers' social mobility. Using a multidimensional approach, different associated indicators were taken into account for measurement. Quantitative method was used. Based on a non-probability sampling, 107 microcredit borrowers were selected for conducting interview schedules. Statistical analysis of data reveals that those who have been taking loans for several number of years have all managed to increase their income level to a variety of extent, but only those have gained some sort of mobility who have been taking loans for more than 4 - 5 years and have taken 5 times or more. Few of them have actually moved from microcredit to become a microfinance client by taking bigger amount of loans and having savings. Positive responses about the indicators being used in the study were found among the handful of those who have mobilized significantly. In true sense, most of the borrowers are stuck at the bottom end of socio-economic ladder and are struggling to manage a better living standard.
\end{abstract}

\section{Keywords}

Microcredit, Social Mobility, Impact, Socio-Economic, Class Position

\section{Introduction}

Microcredit-small amounts of collateral-free institutional loans extended to jointly liable group members for self-employment-was first introduced by the Grameen Bank of Bangladesh in the mid-1970s (Rahman, 2019). The program was launched to provide small loans to the poor and those people who were generally 
excluded from formal financial services. The program soon gained widespread recognition. Since then, it has been in function. However, impact of this program has drawn much controversy over the years. Advocates of this program argue that it reduces poverty, creates employment and generates income. They say, the program eventually results in improved nutrition and improved education of the borrowers' children, and empowerment of the women. Moreover, it is argued that microcredit program has continued to benefit the poor by raising household welfare (Khandker \& Samad, 2014).

As microfinance institutions (MFIs) have been growing in almost all over the country, debate over the effectiveness of microcredit program continues. Usually, people who take part in microcredit program require necessary training and entrepreneurship skills so that they can use the borrowed money in a meaningful way. But many poor populations lack such skills. This is why it is said that any successes may be temporary for them. On top of that, high interest rates have also been found to impoverish clients (Peprah \& Koomson, 2014). By borrowing more money than they can pay back, they may become dependent on MFIs. These may lead them to a further poverty trap.

Many critics say that microcredit program has not increased incomes. It has driven the poor households into a debt trap instead. In fact, there are some cases in which it even leads the borrowers to suicide. Instead of using in a productive way, money from loans is often used for consumption only. It is argued that microcredit has developed innovative management and business strategies by mobilizing the savings and loan repayment, but its impact on poverty reduction remains in doubt (Al Mamun, Hasan, \& Rana, 2013).

One of the most visible recent changes in the lives of rural women in Bangladesh is the significant increase in their access to credit (Mahmud, 2003). Thus, many scholars used to posit that microcredit has brought substantial changes to the pathway of women empowerment (Al-Amin, Hossain, \& Mathbor, 2013). Some people claim that microcredit program enhances the women empowerment in rural areas of Bangladesh (Islam, Ahmed, \& Alam, 2014). However, there is considerable debate on whether microcredit empowers or disempowers women (Aslanbeigui, Oakes, \& Uddin, 2010). Because, it is also reported that it fails to empower women. They say, besides, that the scenario of health and education has not improved either. Therefore, it can be said that microcredit program has achieved much less than what its proponents said it would achieve.

Known as a developing market economy, the economy of Bangladesh is currently the $39^{\text {th }}$ largest in the world in nominal terms and $29^{\text {th }}$ largest by purchasing power parity. In the first quarter of 2019, it was world's seventh fastest growing economy with a rate of $7.3 \%$ real GDP annual growth. In order to hold out such trends, overcoming the barriers that are obstructing the journey of development has become an urgent necessity. In that case, lower and lower middle class people of the country qualify for a special attention. It must be made sure 
that they are not stuck in a position they are currently holding for an indefinite period. They must be able to mobilize forward from their respective positions.

Now what we need to know is whether microcredit program has actually been able to create any impact worth mentioning when the participants' status of social mobility is concerned. The number of participants in this program has been increasing on a continuous basis since its origin, but in which way is this working to change the overall picture of social mobility? In the case of a developing country like Bangladesh, the answer of such questions must be sought.

Major objectives of this research are: 1) to analyze the socio-demographic profile of the participants in microcredit program, 2) to evaluate the socio-economic condition of the microcredit borrowers by developing a comparison between two periods (before participating in microcredit program and current), 3) to examine whether microcredit program brings about any notable changes in their respective social status/social mobility or class position, 4) to assess the impact of microcredit program on borrowers' overall living conditions, and 5) to understand participants' perception about the impact of such programs on their dayto-day living.

\section{Literature Review}

Microcredit is a complex story. There are many layers to interpret in order to understand the various aspects and dynamics of the microcredit model (Fernandez, 2009). The term "microcredit" in modern sense is predominantly used as a tool that enables the borrowers improve their conditions. As this program was devised targeting the poor, the focus is centered on the betterment of them. Different literatures suggest that it is possible to alleviate poverty through microcredit program to some extent, though the opposite statement also exists which implies that this whole thing is nothing but a hoax as there's no way microcredit can reduce poverty.

Karim, Tania, \& Farazi (2012) examined the role of microcredit as a tool to fight poverty. Their study reveals that microcredit programs have generated positive results for large numbers of the poor. Microcredit has significant impacts and ensures the food security. The poor are not homogeneous, so impact varies significantly among different segments of the population according to their socio-economic status, gender, background, family composition and others. Their analysis shows that the poorest borrowers benefit less compared to the middle level poor in general.

Unlike many studies, Chowdhury, Ghosh, \& Wright (2005) empirically examined the impact of microcredit on poverty in Bangladesh by focusing on both objective and subjective poverty and particular attention is paid to the length of time program participants have had access to microcredit. Among the two main findings of that study, the first is that microcredit is associated with both lower objective and subjective poverty. The second is that the impact of microcredit on poverty is particularly strong for about six years with some levelling off after that 
point. The analysis carried out in their study does suggest that microcredit borrowing is associated with lower poverty. However, the effectiveness of microcredit as a real poverty alleviation tool does not depend on its short-run impacts. For microcredit to permanently reduce poverty, it must have a long-run impact.

Zaman (1999) explored the relationship between microcredit and the reduction of poverty and vulnerability by focusing on BRAC, one of the largest microcredit providers in Bangladesh. The main argument in his work is that microcredit contributes to mitigating a number of factors that contribute to vulnerability, whereas the impact on income-poverty is a function of borrowing beyond a certain loan threshold and to a certain extent contingent on how poor the household is to start with. This literature projects that the chances of getting out of the vicious cycle of poverty increase when the amount of loan gets bigger.

However, this cannot be considered as the end of the discussion. Because, larger amount of loan begets bigger debt. Suggestion of Zaman may be effective if the borrower can use the money in a way from which he/she will be able to reap benefit in future. If not, this in turn may worsen his/her existing condition.

Based on extensive survey data from Bangladesh, Khandker (1998) in his book "Fighting Poverty with Microcredit: Experience in Bangladesh" demonstrates that microcredit programs are an effective policy instrument for reducing poverty among poor people with the skills to become self-employed. The book also tells that such programs are more cost effective than some other types of anti-poverty programs; that microcredit programs were found to be particularly important for Bangladeshi women, many of whom are restricted by social custom from seeking wage employment.

Microcredit program has been argued to be potentially effective as a tool for lifting the poor, particularly women, out of poverty. The impact of microcredit program, however, is not limited to improving income of poor women. What is more important is that microcredit program has received much recognition as a viable strategy for empowerment of women, i.e. greater capabilities, choices and freedom in decision-making. Nessa, Ali, \& Abdul-Hakim (2012) examined the impact of microcredit program on women empowerment. They perform regression analysis based on a sample of 600 poor women in eight districts of Rajshahi division, Bangladesh. Based on the results of their study, it is concluded that empowerment of poor women in Bangladesh can be significantly improved by encouraging them to participate in microcredit programs.

Ali \& Hatta (2012) state that MFIs in Bangladesh seem to assess the success of their programs mainly in light of repayment rate and self-sustainability, whereas, the real impact on the beneficiaries is not adequately prioritized. Although longterm microcredit beneficiaries enjoy slightly improved chances of social mobility and have increased feelings of self-worth, there is no significant improvement in securing an enhanced economic base and, at the same time, the longstanding issues of gender disparity and powerlessness remained unchallenged. Thus, the link between minimalist microcredit and women's empowerment is not as strong as it 
is normally perceived.

The number of existing literatures on microcredit program is many. Most of them are associated with the impact assessment of such programs on poverty alleviation and women empowerment. There are several works which have considered issues like women entrepreneurship, their health status, capability to send children to school and so on. However, the impact of this program on the possibility of changes in their mobility status in true sense is yet to be explored. It is expected that such explorations will provide the understanding about the effectiveness of this program a better shape. Attempts have been made in this study to examine whether microcredit program can cause participants' social mobility or not. And if so, to which direction?

\section{Theoretical Framework}

A number of prior studies have analyzed social mobility through both single and multidimensional approaches. However, studies based on a single approach argue that any of occupations, social relations, status, capital etc. is the sole criterion for determining one's social status. But the adherents to the multidimensional approach find the single approach inadequate for analyzing social mobility. Hence, most of the studies analyzing the phenomenon do not help provide a precise and compact model for measuring the actual nature and degree of social mobility. Therefore, attempts have been made, in this study, to measure and analyze social mobility through a theoretical framework based on a multidimensional approach.

According to multidimensional approach, the mobility of a group or individual is determined by multiple dimensions like occupations, consumption pattern, social power as well as social class. The adherents to this approach accept that in the same society, there is a possibility of having a higher rate of mobility in one dimension and a lower in others. Therefore, the derivation of a more accurate conclusion about social mobility is possible only through a multidimensional approach in which one has to consider all the possible dimensions of status-achievement. Thus, dimensions like education, occupation, income, expenditure pattern have been included in this framework developed for the study. To examine the achievement of status and its identification, the dimension of "social class" has also been adopted.

\section{Conceptualizing Social Mobility}

Social mobility refers to movement, either upward or downward between higher or lower social classes. This movement is to be conceived as a process occurring over time, with individuals moving from one role and class position to another because of what has happened to them in various kinds of social interaction. In this sense, mobility provides the individual with more or less of the benefits which his/her economy and society have to offer. A rickshaw puller's son becomes a lawyer; a clerk's son becomes a doctor. In each case, a change in role between 
father and son provides the latter with more of the good things of life.

Social mobility has been conceptualized in this study considering a number of things. They are:

- An overall change in total assets,

- A rise or decline in monthly household income of the individuals,

- Individuals' feeling of economic susceptibility,

- Living conditions,

- Direction of change in consumption pattern,

- Whether children of the individuals go to school or not,

- Where they are receiving healthcare facilities from,

- Accessibility to private healthcare facilities,

- Condition of sanitation facilities, and

- Women's participation in decision-making process within family.

\section{Materials and Methods}

\subsection{Research Method, Study Areas and Sampling}

Using quantitative method, the current study was conducted in three successive stages: first at Raipura (rural), then at Narsingdi Sadar upazila (semi-urban) in Narsingdi district and finally at Jatrabari area of Dhaka city.

Microcredit program in Bangladesh is implemented by Non-Governmental Organizations (NGOs), Grameen Bank, state-owned commercial banks, private commercial banks, and specialized programs of some ministries of Bangladesh Government (MRA, 2014). The population of this study consists of those who have participated in such programs through three particular branches of an NGO located in the study areas. These microcredit borrowers are living in different vulnerable settings of these areas. Through non-probability sampling, 107 borrowers were selected for interview schedules.

\subsection{Data Collection Instruments}

A structured questionnaire with a series of close-ended questions was used as the main data collection instrument. As the respondents of this study are not too educated to understand questions in English, the questionnaire was constructed initially in English and then translated into Bengali. Before data entry, the questionnaire was translated back into English again. While constructing them, due care was given so that response categories were accurate, exhaustive, mutually exclusive and one-dimensional. The questions in the questionnaire included issues such as socio-demographic information, socio-economic condition before and after participating in microcredit program, loan status, impact assessment and their perception.

\subsection{Data Analysis}

Prior to analysis, collected data were checked and rechecked to detect any sort of flaws in data collection. The data then were entered into the software, IBM SPSS 
Statistics. Descriptive statistics was applied to analyze socio-demographic profile, socio-economic conditions, loan status, impact assessment and perception of the respondents about impact. Outcomes of descriptive statistics have been presented through frequency and percentage. Moreover, to establish associations between different variables, 3 chi-square tests and 2 tests of correlation were performed.

\subsection{Ethical Considerations}

Ethical issues were strictly maintained in the study. Though all the participants of this study are clients of the same NGO, name of the NGO was not mentioned anywhere in the study to eliminate any chances (that might surface in future) of causing damages to the reputation of the organization.

It was mandatory that the interviewers introduced themselves and explained the purpose of the study before collecting any information from the respondents. The study registered oral consent from all interviewees. The respondents were informed clearly that the information they would provide during the interview would be kept strictly confidential. The name and address of the respondents were not recorded anywhere in the questionnaires. Furthermore, privacy during the interview process was safeguarded. The interview was held under conditions in which the respondent felt most comfortable in responding openly. It was totally the respondents' discretion to participate in the interview. Any form of coercion on study subjects was strictly avoided in either getting consent or interview.

\section{Findings and Results}

\subsection{Socio-Demographic Profile}

The main clients of microcredit program are those who lack significant amount of land or asset, the people who are struggling against poverty, the destitute who are continuously failing to maintain a sustainable livelihood strategy for them. Again, most of the microcredit recipients are women. In this study, experiences of 107 people are considered who have been taking loans through such programs for different periods of time. Out of them, the number of women is 84 while men are 23 in number (Table 1 ).

However, an interesting pattern is found in the variable "head of the household". All 23 males are the heads of their respective households while all (15) the female-headed households are found among the 84 female respondents. This implies the male-dominant societal trend in Bangladesh. Considering females who are not divorced, the households which are headed by females are only because the money (loan/microcredit) is issued against their name.

Most of the participants are aged between 20 and 30 years. However, it is a general trend that people of this age group are more likely to attempt for obtaining an economic stability in their lives. Among the participants, most of them are married and their educational level varies within primary education. There are cases in which the borrowers obtained education up to secondary level, 
Table 1. Socio-demographic information.

\begin{tabular}{|c|c|c|c|}
\hline Characteristics & Categories & Frequency & Percentage \\
\hline \multirow[b]{2}{*}{ Sex } & Female & 84 & 78.5 \\
\hline & Male & 23 & 21.5 \\
\hline \multirow{2}{*}{ Head of the household } & Female & 15 & 14.0 \\
\hline & Male & 92 & 86.0 \\
\hline \multirow{4}{*}{ Age } & $20-25$ & 46 & 43.0 \\
\hline & $26-30$ & 44 & 41.1 \\
\hline & $31-35$ & 14 & 13.1 \\
\hline & $36-40$ & 3 & 2.8 \\
\hline \multirow{4}{*}{ Marital status } & Unmarried & 2 & 1.9 \\
\hline & Married & 90 & 84.1 \\
\hline & Divorced & 13 & 12.1 \\
\hline & Remarried & 2 & 1.9 \\
\hline \multirow{7}{*}{ Education } & Illiterate & 12 & 11.2 \\
\hline & Can only sign & 3 & 2.8 \\
\hline & Primary incomplete & 31 & 29.0 \\
\hline & Primary completed & 33 & 30.8 \\
\hline & Secondary incomplete & 18 & 16.8 \\
\hline & Secondary completed & 8 & 7.5 \\
\hline & Higher secondary & 2 & 1.9 \\
\hline \multirow{11}{*}{ Occupation } & Small business & 25 & 23.4 \\
\hline & Medium business & 6 & 5.6 \\
\hline & Family owned business & 7 & 6.5 \\
\hline & Housewife & 53 & 49.5 \\
\hline & Farmer & 2 & 1.9 \\
\hline & Agricultural laborer & 1 & 0.9 \\
\hline & Day laborer & 2 & 1.9 \\
\hline & Construction worker & 2 & 1.9 \\
\hline & Rickshaw/van/cart puller & 5 & 4.7 \\
\hline & Transport worker & 2 & 1.9 \\
\hline & Small job/service holder & 2 & 1.9 \\
\hline \multirow{3}{*}{ Type of residence } & Rural & 65 & 60.7 \\
\hline & Semi-urban & 30 & 28.0 \\
\hline & Urban & 12 & 11.2 \\
\hline
\end{tabular}


but couldn't carry on due to the lack of economic support from family. As education is considered an important indicator of success in the lives of individuals, it can be assumed that those who didn't obtain enough education are more likely to fall victims of sufferings or poverty.

25 of the total participants in this study are involved in different small businesses. 53 women are housewives. The rest are in a variety of works ranging from day laborer to family owned businesses or small jobs/services. Usually, one of the common patterns in microcredit program is that most of its clients are those who live in rural and semi-urban areas rather than in urban areas. The pattern was followed in this study. Among the 107 borrowers, the number of rural and semi-urban dwellers are 65 and 30 in order while urban dwellers comprise 12 .

\subsection{Socio-Economic Condition}

In most cases, income level of the participants fell between below Taka 5000 and Taka 10,000 during the period when they didn't borrow money through microcredit program. But current income level ranges from Taka 5000 to Taka 25,000 for most of the respondents (Table 2). Though the change in the level of income clearly implies that income of many respondents have increased over the period, it is too early to reach a conclusion as the condition of economy has changed over the years too. Increase in income is not enough in many cases to improve the living condition as living expenses have also increased in the meantime.

Table 2. Socio-economic condition.

\begin{tabular}{|c|c|c|c|}
\hline Characteristics & Categories & Frequency & Percentage \\
\hline & below 5000 & 52 & 48.6 \\
\hline \multirow{5}{*}{$\begin{array}{l}\text { Monthly household income } \\
\text { before taking loans }\end{array}$} & $5000-10,000$ & 53 & 49.5 \\
\hline & $11,000-15,000$ & 2 & 1.9 \\
\hline & below 5000 & 3 & 2.8 \\
\hline & $5000-10,000$ & 55 & 51.4 \\
\hline & $11,000-15,000$ & 26 & 24.3 \\
\hline \multirow{6}{*}{$\begin{array}{l}\text { Current monthly } \\
\text { household income }\end{array}$} & $16,000-20,000$ & 9 & 8.4 \\
\hline & $21,000-25,000$ & 6 & 5.6 \\
\hline & $26,000-30,000$ & 1 & 0.9 \\
\hline & $51,000-60,000$ & 5 & 4.7 \\
\hline & $61,000-70,000$ & 2 & 1.9 \\
\hline & Yes & 62 & 57.9 \\
\hline \multicolumn{4}{|l|}{ Increase in total assets } \\
\hline & No & 45 & 42.1 \\
\hline
\end{tabular}


As the monthly household income increases, so does the monthly household expenditure. Though it is a general trend that the more one earns, the more does he/she spend than before. Increase in income means the increase in capability to spend money in ways that one wasn't capable of before. However, one significant improvement is that 39 out of 107 participants now have monthly savings compared to the period when they didn't take loans and didn't have any savings either. Their current monthly savings ranges from Taka 500 to more than 5000 . 22 of them have savings between Taka 500 and Taka 1000 while the rest have more.

Among all the respondents, the number of people who reported that their total assets have increased over the years is 62. Considering change in the house possession, the number of people who had houses of their own was 61 when they hadn't taken part in microcredit program. But the number has increased to 69 over the years. Increase in the number of earning members in the family is also evident. It is found that the cases in which total assets have increased, earning members in the family have also increased. In a sense, this increase might have contributed to the increased income of that particular household.

\subsection{Class Position}

Almost half of the world's population, with incomes of less than USD 1 to about USD 4, are counted as poor and live almost entirely in the developing world. Another 40 percent of the world's population, with income between USD 4 to USD 50 a day, make up an "incipient" (below USD 10 a day) middle class; with the exception of a small proportion of that group living in rich countries, this is the "new" middle class of the developing world. A much smaller rich world middle class has income between USD 50 to USD 200 (Mujeri, 2019).

The only determinant of measuring class position based on income is "income". To measure class position in this study, monthly household income (Table 3) was considered for each of the participants. Again, their level of income in both periods (before participating in microcredit program and current) were taken into account. By doing so, presence of change in class position to some extent was found.

Table 3. Income class groups.

\begin{tabular}{ccc}
\hline Income class & $\begin{array}{c}\text { Income in USD } \\
\text { (per day) }\end{array}$ & $\begin{array}{c}\text { Income in BDT } \\
\text { (per month) }\end{array}$ \\
\hline Poor & below $1-4$ & below $2549.4-10,197.6$ \\
"Incipient" middle class & 4 - below 10 & $10,197.6$ - below 25,494 \\
Middle class & 10 - below 50 & 25,494 - below 127,470 \\
Middle class (Rich world) & $50-200$ & $127,470-509,880$
\end{tabular}

${ }^{*}$ Calculating USD $1=$ BDT 84.98 as of February 22, 2020. 
It is revealed that all but 2 of them belonged to poor/lower class based on income before taking loans. But over the years, 41 of them have elevated to an "incipient" middle class while another 8 have successfully managed to move in the middle class.

99 of the total participants have said that they are first in their families to take part in microcredit program. However, 41 of them have actually managed to move within the class positions based on income. Those 41 have elevated from poor/lower class to either an "incipient" middle class or middle class implying intra-generational mobility.

On the other hand, 8 participants who have responded that they aren't first in their families to take part have all made changes in their respective "class position". The first ones who took loan in those families are actually their mother or father. This type of mobility is termed as inter-generational mobility.

\subsection{Loan Status}

According to a latest report in a national daily, the Microcredit Regulatory Authority (MRA) of Bangladesh has formulated draft guidelines to permit the MFIs so that they can provide collateral-free loans of up to Taka 4 million for micro enterprises to help boost the country's small and medium enterprises (Hossain, 2020). However, in reality, such guidelines are being practiced by the MFIs here for several years now. Thus, many respondents have bigger amount of loans that they were not supposed to get as clients of microcredit program.

Current amount of loan taken by the participants ranges from Taka 50,000 to Taka 500,000. 13.1\% respondents have loan of Taka 50,000. 25.2\% of the respondents have current loan of Taka 200,000. The percentages of other amount categories are shown below (Table 4 ).

The respondents of this study are involved with microcredit program for 1 to 10 years. $53.3 \%$ of the respondents have been taking loans through microcredit program for 3 - 5 years. Only $2.8 \%$ of the respondents are involved for the last 9 - 10 years. The percentages of 1 - 2 and 6 - 8 years are 13.1 and 30.8 respectively. Considering the notions "increase in monthly household income" and "increase in total assets", it is evident that people who have been taking loans for more than 4 - 5 years and have taken 5 times or more are more likely than others to bring about a positive change in these indicators.

Loan repayment remains the major difficulty when it comes to women's control over loan use (Develtere \& Huybrechts, 2005). In Bangladesh, since men do the income generating activities in most cases and thus responsible for the loan repayment, usually they decide how the money would be utilized. Out of 107 respondents, it is found that all the male borrowers utilize the money the way they want. On the other hand, out of 84 female respondents being interviewed, only $20.2 \%$ can use their borrowed money as they wish. Among those 84 , though the loans are actually sanctioned against their names, $79.8 \%$ of the respondents reported about their money being taken away by their respective husbands and 
Table 4. Loan status.

\begin{tabular}{|c|c|c|c|}
\hline Characteristics & Categories & Frequency & Percentage \\
\hline \multirow{6}{*}{ Amount of loan } & 50,000 & 14 & 13.1 \\
\hline & 100,000 & 18 & 16.8 \\
\hline & 150,000 & 12 & 11.2 \\
\hline & 200,000 & 27 & 25.2 \\
\hline & 300,000 & 17 & 15.9 \\
\hline & 500,000 & 19 & 17.8 \\
\hline \multirow{4}{*}{ Number of years } & $1-2$ & 14 & 13.1 \\
\hline & $3-5$ & 57 & 53.3 \\
\hline & $6-8$ & 33 & 30.8 \\
\hline & $9-10$ & 3 & 2.8 \\
\hline \multirow{5}{*}{ Number of times } & 2 & 14 & 13.1 \\
\hline & 3 & 18 & 16.8 \\
\hline & 4 & 39 & 36.4 \\
\hline & 5 & 34 & 31.8 \\
\hline & more than 6 & 2 & 1.9 \\
\hline \multirow{2}{*}{ Loan utilizer } & Himself/herself & 33 & 30.8 \\
\hline & Spouse & 74 & 69.2 \\
\hline
\end{tabular}

utilized based on their individual decisions. In maximum cases, wife's opinion is not considered.

\subsection{Impact Assessment}

A number of indicators have been used in this study to assess the impact of microcredit program on the lives of the respondents and their perception about such impacts. Some of them are: 1) whether they feel economically more susceptible or not (compared to the period when they didn't take part in microcredit program), 2) access to all the facilities necessary for their livelihood, 3) change in consumption pattern, 4) balanced diet, 5) proper sanitation facilities, 6) access to healthcare facilities, 7) access to education for their children, and 8) women's participation in decision-making process.

Those who have responded positively (Table 5) to these indicators have all mobilized within class positions. Many of the respondents who managed to increase their monthly household income and total assets-though failed to obtain significant social mobility—also answered positively when asked about these indicators. But most of them who haven't mobilized replied in a negative manner implying that participating in microcredit program hasn't brought any signifi- 
cant changes to their lives.

From the fact that a part of household income now accrues to or through women, one would expect a greater participation of women in household decisionmaking (Kelkar, Nathan, \& Jahan, 2004). But out of 84 women participated in the study, only 19 of them have reported that they can participate in the decision-making process to some extent. Still, it doesn't necessarily mean that their decision is always taken into account.

According to Sharif (2004), while it is relatively easy for women to move toward "joint" decision-making status, it is much more difficult going beyond that. However, in this study, not a single case was found in which the woman reported to have "joint" decision-making status. They say, "We just express our thoughts. There are many women here who don't even get this opportunity. So,

Table 5. Impact assessment.

\begin{tabular}{|c|c|c|c|}
\hline Characteristics & Categories & Frequency & Percentage \\
\hline & Yes & 56 & 52.3 \\
\hline \multicolumn{4}{|l|}{ Economic susceptibility } \\
\hline & No & 51 & 47.7 \\
\hline & Yes & 62 & 57.9 \\
\hline \multicolumn{4}{|l|}{ Balanced diet } \\
\hline & No & 45 & 42.1 \\
\hline \multirow{3}{*}{ Change in consumption patter } & Yes & 96 & 89.7 \\
\hline & & & \\
\hline & No & 11 & 10.3 \\
\hline \multirow{3}{*}{ Direction of change } & Better & 61 & 63.5 \\
\hline & & & \\
\hline & Worse & 35 & 36.5 \\
\hline \multirow{3}{*}{ Access to necessary facilities } & Yes & 39 & 36.4 \\
\hline & & & \\
\hline & No & 68 & 63.6 \\
\hline \multirow{3}{*}{ Do children go to school? } & Yes & 100 & 96.2 \\
\hline & & & \\
\hline & No & 4 & 3.8 \\
\hline \multirow{3}{*}{ Proper sanitation facilities } & Yes & 82 & 76.6 \\
\hline & No & 20 & 18.7 \\
\hline & Can't say & 5 & 4.7 \\
\hline \multirow{5}{*}{ Source of healthcare } & Homeopath & 4 & 3.7 \\
\hline & Kabiraj & 2 & 1.9 \\
\hline & & & \\
\hline & Doctor & 65 & 60.8 \\
\hline & Local pharmacist & 36 & 33.6 \\
\hline \multirow{2}{*}{$\begin{array}{c}\text { Women's participation in } \\
\text { decision-making }\end{array}$} & Yes & 19 & 22.6 \\
\hline & No & 65 & 77.4 \\
\hline
\end{tabular}


we' re happy that we can at least talk." In most cases, it's totally the wish of their respective husbands whether they'll take those thoughts into account or not.

\subsection{Statistical Inference}

1) Is there any relationship between sex of the respondent and increase in monthly household income?

2) Is there any relationship between level of education and increase in monthly household income?

3) Is there any relationship between number of years respondent has been taking loans through microcredit program and increase in monthly household income?

Performing Pearson Chi-Square test, the answers of these research questions have been determined. In a chi-square test, the result is significant if the value is equal to or less than the designated alpha level (normally 0.05 ). The $p$-values in the three cases considered here are smaller than the standard alpha value (Table 6), so the null hypotheses have been rejected which assert that the two variables in each of the research questions are independent of each other. To put it simply, the result is significant. The data suggest that the variables in every research question are associated with each other. Therefore, it can be said that those borrowers have higher chances of obtaining increase in monthly household income who are men, or have more years of schooling, or have been taking loans for more years than others.

Table 7 presents statistical values for two tests of correlation. The value of

Table 6. Chi-square tests.

\begin{tabular}{|c|c|c|c|c|}
\hline Research Question & & Value & df & Asymp. Sig. (2-sided) \\
\hline 1 & Pearson & 10.120 & 1 & 0.001 \\
\hline 2 & Chi-Square & 103.029 & 6 & 0.000 \\
\hline 3 & & 71.937 & 9 & 0.000 \\
\hline
\end{tabular}

Table 7. Correlations.

\begin{tabular}{|c|c|c|c|}
\hline \multicolumn{2}{|c|}{ Correlation 1} & $\begin{array}{l}\text { Earning members in the } \\
\text { family }\end{array}$ & $\begin{array}{l}\text { Monthly household } \\
\text { income }\end{array}$ \\
\hline & Pearson Correlation & 1 & 0.604 \\
\hline \multirow{2}{*}{$\begin{array}{l}\text { Earning members in the } \\
\text { family }\end{array}$} & Sig. (2-tailed) & & 0.000 \\
\hline & $\mathrm{N}$ & 107 & 107 \\
\hline \multicolumn{2}{|c|}{ Correlation 2} & $\begin{array}{l}\text { Current amount } \\
\text { of loan }\end{array}$ & $\begin{array}{l}\text { Monthly household } \\
\text { income }\end{array}$ \\
\hline \multirow{3}{*}{$\begin{array}{l}\text { Current amount } \\
\text { of loan }\end{array}$} & Pearson Correlation & 1 & 0.720 \\
\hline & Sig. (2-tailed) & & 0.000 \\
\hline & $\mathrm{N}$ & 107 & 107 \\
\hline
\end{tabular}


Pearson correlation varies between +1 and -1 where +1 is a perfect positive correlation and -1 is a perfect negative correlation. 0 means there is no linear correlation at all. In correlation 1 , the figure of 0.604 indicates a strong, positive and linear correlation. Thus more the number of earning members in the family increases, more the income is likely to increase. Similarly, in the case of correlation 2 , the figure 0.720 indicates a strong, positive and linear correlation between current amount of loan and monthly household income. In other words, increase in the amount of loan for a respondent causes increase in monthly household income.

\section{Discussion}

Based on the collected data and statistical analysis, the researchers have come across a number of realizations. First, poverty-stricken people are the main clients of microcredit program. Considering gender distribution, women are more in number than men. But in most cases, the money is taken away by their respective husbands and is used in the way they want.

Second, the percentage of "increase in income" is relatively high among the male borrowers. It is also evident that those who have had more schooling are more likely to increase their income. Moreover, number of earning members in the family is also a catalyst of better income generation.

Third, those who have been taking loans for several number of years (in some cases, have actually moved to become a client of microfinance services by taking bigger loans and having savings) have all managed to increase their respective income levels. But in most of the cases, they are failing to manage an improved living condition as commodity price hasn't remained the same anymore. Day-today living has become costlier than before.

Fourth, based on income, many of the respondents of this study have moved to belong either in an "incipient" middle class or in a middle class. Instances of inter-generational mobility are more in percentage than intra-generational mobility. However, such an income class mobilization has hardly contributed to their living conditions. There are number of cases in which significant mobility is observed, but most of the participants are struggling to maintain a sustainable living.

Fifth, borrowers in this study who have been taking loans for more than 4 - 5 years and have taken 5 times or more are more likely to gain some sort of mobility than others. As argued in different literatures, microcredit program may be effective if it runs for a longer period of time.

Sixth, positive responses are found among those who have mobilized to a significant extent when asked about the issues like household income, economic susceptibility, living conditions, consumption pattern, children's education, healthcare facilities, women's participation in decision-making etc. Though many of the respondents in this study have agreed that they feel economically more susceptible now compared to the period when they didn't take loans, they have 
confessed that they haven't gained any significant improvement yet.

Seventh, in spite of significant inter-country differences, it is generally the case that, in the developing countries, women do worse than men, whether one looks at education, nutritional status, wealth or income, mobility, etc. (Sharif, 2001). The same is true for the current study.

Finally, issues addressed by microcredit program such as poverty alleviation, women empowerment, social mobility etc. have all showed some positive changes in this study. But they are hardly enough. They don't resemble the claims microcredit program used to advertise and this is very much unexpected after so many years of the program in business. Therefore, effective redesigning of microcredit program has become an urgency if benefit in actual sense is sought.

\section{Conclusion}

Microcredit, originated in Bangladesh has spread all over the globe (Ahmed, 2004). However, there remains some aspects the program should emphasize on. This study attempted to understand the impact of the program on mobility status of some borrowers from Bangladesh. Unfortunately, the findings are not so promising. Though the results of this study may not be universalized as society, economy and people's ways of living vary from country to country, we must agree that microcredit program should give more importance on how their clients can make good use of the money they borrow. Spending in ways that have potential to produce money may cause the mobilization we are seeking.

\section{Recommendations}

To make microcredit program more effective, different steps should be taken. Following are some recommendations:

- Traditionally, MFIs have required clients to use loans solely for investment in their own business. But insisting the borrowers to invest only in their businesses may impact them negatively. Rather, giving them effective suggestions about "how they can use the money in a productive way so that they can generate income from that" would be a better idea.

- In some cases, borrowers may lack skills and training along with suggestions. Microcredit program can include skill development training and workshops in their schedule to enable them in overcoming such barriers.

- As found in this study, borrowers who have been taking loans for several years are likely to gain some mobility. Hence, it would be wise for microcredit program to help them maintain repayment schedule so that they don't drop out as defaulters.

- Rather than assuming that loan repayment guarantees positive impact, attention should be given to the ways following which they are repaying loans. The sooner it will be ensured that they are doing some productive works, the better will be the chances for them to have some improvement in their lives.

- Last but not the least, microcredit program will be more effective if clients 
individual needs are met more precisely. The key factor is listening to the client. If the program can ensure this, financial services oriented to clients' needs and women's needs in particular will be more effective at really making a difference.

\section{Acknowledgements}

The authors sincerely thank all the participants in this study, all those beloved friends who willingly helped and supported in every possible way, and the anonymous reviewers who put their efforts to make this work publishable.

\section{Conflicts of Interest}

The authors declare no conflicts of interest regarding the publication of this paper.

\section{References}

Ahmed, S. (2004). Microcredit in Bangladesh: Achievements and Challenges. Microfinance Gateway.

https://www.findevgateway.org/sites/default/files/mfg-en-casestudy-microcredit-in-ba ngladesh-achievements-and-challenges-2004.pdf

Al Mamun, C. A., Hasan, M. N., \& Rana, A. (2013). Micro-Credit and Poverty Alleviation: The Case of Bangladesh. World Journal of Social Sciences, 3, 102-108.

Al-Amin, M., Hossain, M. I., \& Mathbor, G. M. (2013). Women Empowerment through Microcredit: Rhetoric or Reality? An Evidence from Bangladesh. Multidisciplinary Journal of Gender Studies, 2, 107-126.

Ali, I., \& Hatta, Z. A. (2012). Women's Empowerment or Disempowerment through Microfinance: Evidence from Bangladesh. Asian Social Work and Policy Review, 6, 111-121. https://doi.org/10.1111/j.1753-1411.2012.00066.x

Aslanbeigui, N., Oakes, G., \& Uddin, N. (2010). Assessing Microcredit in Bangladesh: A Critique of the Concept of Empowerment. Review of Political Economy, 22, 181-204. https://doi.org/10.1080/09538251003665446

Chowdhury, M. J. A., Ghosh, D., \& Wright, R. E. (2005). The Impact of Micro-Credit on Poverty: Evidence from Bangladesh. Progress in Development Studies, 5, 298-309. https://doi.org/10.1191/1464993405ps116oa

Develtere, P., \& Huybrechts, A. (2005). The Impact of Microcredit on the Poor in Bangladesh. Alternatives, 30, 165-189. https://doi.org/10.1177/030437540503000203

Fernandez, A. J. (2009). Microcredit and Women's Outward Mobility in Rural Bangladesh: A Study of the Grameen Bank. Master's Thesis, Long Beach, CA: California State University.

Hossain, I. (2020). MFIs Can Now Provide up to Tk 4m Collateral-Free Loan: MRA Formulates Draft Guidelines. The Financial Express.

https://thefinancialexpress.com.bd/trade/mfis-can-now-provide-up-to-tk-4m-collateral -free-loan-1582605632

Islam, M. S., Ahmed, M. F., \& Alam, M. S. (2014). The Role of Microcredit Program on Women Empowerment: Empirical Evidence from Rural Bangladesh. Developing Country Studies, 4, 90-97.

Karim, M. R., Tania, S., \& Farazi, M. M. R. (2012). Role of Micro-Credit in Poverty Al- 
leviation of Rural Poor: Evidence from Laxmipur District of Bangladesh. Journal of Business and Technology (Dhaka), 7, 37-55. https://doi.org/10.3329/jbt.v7i2.16453

Kelkar, G., Nathan, D., \& Jahan, R. (2004). Redefining Women's “Samman”: Microcredit and Gender Relations in Rural Bangladesh. Economic and Political Weekly, 39, 36273640.

Khandker, S. R. (1998). Fighting Poverty with Microcredit: Experience in Bangladesh. Oxford: Oxford University Press.

Khandker, S. R., \& Samad, H. A. (2014). Dynamic Effects of Microcredit in Bangladesh. Policy Research Working Paper 6821. Washington DC: Development Research Group, The World Bank. https://doi.org/10.1596/1813-9450-6821

Mahmud, S. (2003). Actually How Empowering Is Microcredit? Development and Change, 34, 577-605. https://doi.org/10.1111/1467-7660.00320

Microcredit Regulatory Authority (MRA) (2014). An Overview of Microcredit in Bangladesh. Microcredit in Bangladesh.

https://www.mra.gov.bd/images/mra files/News/mcinbd17082015.pdf

Mujeri, M. K. (2019). The "Middle-Class" in Bangladesh: Winners or Losers? The Daily Star.

https://www.thedailystar.net/opinion/economics/news/the-middle-class-bangladesh-wi nners-or-losers-1762765

Nessa, T., Ali, J., \& Abdul-Hakim, R. (2012). The Impact of Microcredit Program on Women Empowerment: Evidence from Bangladesh. OIDA International Journal of Sustainable Development, 3, 11-20.

Peprah, J. A., \& Koomson, I. (2014). Addiction to Microcredit: An Obstacle to Social and Financial Mobility. Munich Personal RePEc Archive.

https://mpra.ub.uni-muenchen.de/57894 https://doi.org/10.2139/ssrn.2976094

Rahman, A. (2019). Women and Microcredit in Rural Bangladesh: An Anthropological Study of Grameen Bank Lending. Abingdon-on-Thames: Routledge. https://doi.org/10.4324/9780429503023

Sharif, N. R. (2001). Poor Female Youth and Human Capital Development in Bangladesh: What Role for Micro-Credit Programmes? In Women and Credit: Researching the Past, Refiguring the Future (Vol. 24, pp. 223-242). Abingdon-on-Thames: Routledge. https://doi.org/10.4324/9781003103233-17

Sharif, N. R. (2004). Microcredit Programs and Women's Decision-Making Status: Further Evidence from Bangladesh. Canadian Journal of Development Studies, 25, 465-480. https://doi.org/10.1080/02255189.2004.9668989

Zaman, H. (1999). Assessing the Poverty and Vulnerability Impact of Micro-Credit in Bangladesh: A Case Study of BRAC. Washington DC: World Bank, Development Economics, Office of the Senior Vice President and Chief Economist. 